\title{
Use of Integration Strategy on Competitive Performance of Rabbit Meat Production Firms in Kenya
}

\author{
Catherine Wanjiku Kimani ${ }^{1}$, Barrack Okello ${ }^{2}$, Juma Wagoki ${ }^{3}$ \\ Department of Accounting \& Commerce, Jomo Kenyatta University of Agriculture \& Technology. Juja, Kenya
}

\begin{abstract}
This study was aimed at finding out the use of integration strategies for competitive performance of rabbit meat production firms in Kenya and if there is any influence of the integration strategies on competitive performance of the rabbit meat production firms in Kenya. The study was guided by the following objectives; to analyse the effect of vertical integration strategy on competitive performance of the rabbit meat industry in Kenya, to establish the effect of horizontal integration strategy on competitive performance of the rabbit meat industry in Kenya and to analyse the effect of diagonal integration strategy on competitive performance of the rabbit meat industry in Kenya. The study collected data from production managers and farm managers. It used descriptive analysis for individual research indicators while correlation and regression analysis were used to establish the effect of vertical, horizontal and diagonal integration on competitive performance. Empirically, using Pearson correlation $r$ and significance value $p$, vertical integration was found to contribute to $62.7 \%$ i.e. $r^{\wedge} 2=0.632$ at $(r=0.795 ; p<0.01)$ of the positive variation in competitive performance of these firms. On the other hand, diagonal integration was found to contribute $51.9 \%$ i.e. $r^{\wedge} 2=0.519$ at $(r=0.721 ; p<0.01)$ while horizontal integration was found to insignificantly contribute $1.5 \%$ i.e. $r^{\wedge} 2=0.015$ at $(r=0.126 ; p<0.01)$. From the regression analysis, $R=0.860$ and $R^{\wedge} 2=0.74$ indicate that $74 \%$ of changes in competitive performance of the firms was attributed to collective use of vertical, horizontal and diagonal integration. The study recommended that; firms should have in place internal organizational policy and culture that encourages vertical integration and put into place internal organizational structures that allow cross flow of information so as to allow adoption diagonal integration. Further studies were suggested on the critical success factors for successful adoption of vertical and diagonal integration and on the role of management in adoption of integration strategies in production environment especially with specific interest on vertical and diagonal integration.
\end{abstract}

Keywords: Integration Strategy, Competitive Performance, Rabbit Meat Production Firms

\section{Introduction}

Entrepreneurial strategies are becoming more and more important for both upcoming and existing businesses (Bett \& Hitt, 1995). Due to increasing dynamism in the business environment as well as intensifying global competition, businesses are compelled to build more entrepreneurial strategies for them to compete and survive regardless of their age or size (Meyer et al., 2002). For more competitive performance, firms must practice entrepreneurship strategy which is an integration of entrepreneurial (opportunity seeking behaviour) and strategic (advantage seeking behaviour) perspectives to design and implement entrepreneurial strategies for superior firm performance (Hitt et al., 2001).

Some of the strategies that are suitable for firms in turbulent business environments include related and unrelated diversification; intensive strategies of market penetration, market development and product development; defensive strategies of divestiture and liquidation as well as horizontal, diagonal and vertical (both forward and backward) integration strategies.

In this case, integration is an entrepreneurship strategy applicable to the rabbit meat industry in Kenya having been proven to work in other rabbit meat industries across the world especially in China and Hungary (Yan, 2011). It has also been proven to work in other meat industries such as the poultry and pork industry in the Asia-Pacific region and resulted to double digit growth (Larsen, 2012).

According to Besanko et al., (2007) firms are increasingly choosing to integrate vertically hence choose to produce the raw materials and even distribute the finished goods themselves instead of depending on independent suppliers, factors and agents. Vertical integration is a strategy where a single firm produces complementary products and services more profitably than a number of firms (Berlin 2001). Activities are considered complementary when carrying out one activity minimises the cost of doing the other. Vertical integration is also referred to as the common organization of an industry across a number of components of the value chain, and increased standardization of production at each stage of the production process. Vertical integration increases technical efficiencies in co-coordinating, monitoring and enforcement of the production process (Sudarsanam, 2010).

According to Dobashi et al., (1999) vertical integration can be applied in three levels namely non-integration, semiintegration (quasi-integrated) and full integration. Quasi integration is either upstream or downstream. Firms can also apply taper vertical integration where they could be backward or forward integrated but rely on outsiders for a portion of their supplies or distribution such that they can control the research and development of the outsiders, reduce vulnerability to strikes and shortages within their systems and examine the products of competitors while enjoying the lower costs, greater profit margins and greater advantages of 


\section{International Journal of Science and Research (IJSR) \\ ISSN (Online): 2319-7064 \\ Index Copernicus Value (2013): 6.14 | Impact Factor (2015): 6.391}

vertical integration. In the rabbit meat industry this could mean inclusion of individual farmers or co-operatives in supply and distribution of products of an already integrated firm.

While business performance is defined as the total economic result of the activities an organization undertakes competitive performance is viewed as the ability to sustain trade against the competition in the global market (Lusch \& Laczniac, 1989), Competitive performance implies the profitable creation and delivery of competitive advantage reflected in superior organizational profitability relative to one's industry or other benchmark (Serra, 2004).

Most researchers view competitive advantage as a direct predecessor of competitive performance, or as a basis for attaining competitive performance. Sera further notes that most theorists agree on the relative nature of competitive advantage and the multiple ways of achieving the same. Consequently, to attain competitive advantage a firm should not necessarily be the best in all dimensions, but it has to take superiority in value creation (Navaro et al., 2010). In addition, it is essential to emphasize that competitive advantage has relative and no definite meaning, since a firm can only have advantage in relation to its competitors (Powell, 2001).

Even though substantial amount of research treats competitive advantage and performance as synonyms, or derives the existence of competitive advantage from observed competitive performance, according to significant number of authors, that view is not correct (Sera, 2004). Competitive advantage directly precedes achieving competitive performance (Navaro et al., 2010). However, though sustainable competitive advantage is necessary for competitive performance, it is not a sufficient basis. A firm's relative competitive advantage defines its profitability. (Powell, 2001). This is because the firm's achievement of competitive advantage shall reduce the cost and hence improve all the financial indicators like return on investment (ROI), capital growth, profit growth and sales growth (Miller et al, 2001). Superior quality as a competitive advantage increases market share so that all the financial indicators improve. Both cost and quality advantage increases the number of customers for a firm.

\subsection{Statement of the Problem}

The rabbit sector has the potential to overcome challenges of a growing world population by supplying a healthy wholesome food product and provide a source of income and employment. More than 1.2 billion rabbits are slaughtered for meat globally every year producing over 1.8 million tones of rabbit meat with China representing of $40 \%$ of the total population. Rabbits are the second most farmed species in Europe which globally holds almost $90 \%$ of the exports and $30 \%$ of the imports. Export of rabbit meat from China adds to the contribution by the agricultural sector in China's economy, valued at $10 \%$ implying that it evidently counts in making China the second largest economy in the world since 2010 with respect to gross domestic product. In Hungary 96$97 \%$ of the slaughtered rabbit meat is exported and only 3-
$4 \%$ is consumed locally. Hungary annually returns on average 25million US Dollars from the sale of rabbit meat. Between the year 2000 and 2010, Kenya's highest export value was recorded at 6125 US Dollars in 2008 (MoLD, 2015). This is incomparable for example with the Hungarian average of 25 million US Dollars annually. An overview of the rabbit meat industry in countries described earlier correlate dominance in the level of productivity and commercialization. Also, it associates intensive rearing, established marketing systems and modern strategies of management with dominance in productivity levels,higher market share, foreign exchange earnings, food security, better nutrition, employment opportunities and personal income for all involved. This lacks in the Kenya rabbit meat sector hence unexploited foreign exchange earner, untapped highly nutritive food basket and unrealized employment opportunities. Integration strategies as used in the Italian rabbit meat sector and poultry and fishery sector in Nigeria have the potential of propelling the rabbit industry in Kenya to full potential.

\subsection{Research Objectives}

1)To analyse the effect of vertical integration strategy on competitive performance of the rabbit meat industry in Kenya.

2)To establish the effect of horizontal integration strategy on competitive performance of the rabbit meat industry in Kenya.

3)To analyse the effect of diagonal integration strategy on competitive performance of the rabbit meat industry in Kenya.

\section{Literature Review}

\subsection{Theoretical Review}

\subsubsection{Transaction Cost Theory (TCT)}

According to Jones (1998) the boundaries of the firm was ascertained in light of transaction costs hence the theory of transaction costs which is also referred to as the theory of transaction cost economies (TCE). TCT claims that these transaction costs driving economic organization are as important as production costs, or perhaps even more important. The transaction cost economics framework recognizes that vertical integration has both costs and benefits from the firms' perspectives.

TCT rests upon many assumptions. Under human behavior, TCT assumes that individuals may engage in subtly and overtly deceitful behavior, ex-ante and ex-post to agreeing on contracts and in the absence of potentially opportunistic behavior contracts would be costless enforced and there would be no reason for other forms of economic organizations besides the market. Second is the assumption of bounded rationality where TCT reflects individuals inability to process large degrees of information and their difficulty in assigning probability values to the occurrence of future events. Under environmental characteristics TCT assumes asset specificity and also assumes uncertainty where without bounded rationality and opportunism, uncertainty would be much less.

\section{Volume 5 Issue 4, April 2016}




\section{International Journal of Science and Research (IJSR) \\ ISSN (Online): 2319-7064}

Index Copernicus Value (2013): 6.14 | Impact Factor (2015): 6.391

TCT also majorly assumes frequency of transactions where if infrequent, cost of alternative governance structure may not be justified. Also, Williamson (1975) identified three determinants of the transaction costs namely the agents' bounded rationality, opportunism the assets specificity. Critiques of transaction costs economics have argued that market power may be the fundamental motivation behind the push towards vertical integration and the development of contractual arrangements.

Williamson responded to such criticisms by restating that in his model, opportunism or bounded rationality may differ from person to person but when transaction costs change they do so because of changes in the environment, not in the person (Williamson, 1993a,b). Although far less voiced, the criticisms on the assumption of bounded rationality and uncertainty still exist. Jones (1998) adopted a positive or entrepreneurial view and argued that bounded rationality and uncertainty are not problems to be managed and overcome, but rather are opportunities to be taken advantage of. Another critic to TCT is its tautological nature. Eccles (1987) claimed that Williamson failed to operationalize the measurements of transaction costs but Williamson distinguished ex ante costs (such as negotiation costs) from ex post costs (such as costs associated with contractual failures), it is hard to find any costs that are not transaction costs. In a nutshell, TCT is about efficiency and views economic organization as being predominantly concerned with the relative efficiency of optimizing on transaction costs. Like in any other industry, the rabbit meat industry incurs transaction costs in the form of information costs, negotiation costs as well as monitoring costs.

China, has always had to make the decision between selling live rabbits or rabbit meat in the form of carcasses depending on the market they sell to (Chen, 2011). In the Kenyan market, a deeper look into these costs will allow the players in the rabbit meat sector to minimize on the transaction costs involved while at the same time maximize on probable contracts and mergers that would arise as a result of integration.

\subsubsection{Agency Theory}

Agency theory explains why one party (the principal) determines the work for which another party (the agent) undertakes (Jensen \& Meckling, 1976). An agent has an incentive to avoid and the principal must structure the transaction such that the agent does not evade. While this theory has been used to explain contractual arrangements, in circumstances where a principal cannot structure such a contract, actual integration will occur. All contracts are formed because the parties involved expect to benefit. Agency theory is concerned with resolving tow problems that can occur in contracts ie the issue of goals of the principal and agent conflicting and when its difficult of expensive for the principal to verify what the agent is actually doing. The agency structure is applicable to both vertical and horizontal integration (Williamson, 1999).

Agency theory rests on the human assumptions of selfinterest, bounded rationality and risk aversion; information assumption of information as a purchaseable commodity; and organizational assumptions of partial goal conflict among participants, efficiency as the effectiveness criterion and information asymmetry between principal and agent.Agency theory has been tested in the poultry industry in America. Shelden (1996) adopts a principal-agent framework to characterize contracts as providing incentive for effort by rewarding growers on the basis of output, but at the cost of imposing risk on them.

This scheme, shifts risks which are common to all growers (weather, feed mix, chick genetics) to the integrator company (Holmström, 1982). Second, these contracts automatically shift all of the gains from innovation (increases in absolute performance) to the integrator company. As a result, those making adoption decisions face the full costs and benefits of these decisions without the necessity to rewrite contracts (no additional contracting costs are incurred).

Shapiro (2005) argued that the agency theory (AT) perspective is a peculiar way of understanding the social reality, that the assumptions therein are detached from reality and purely made in order for the model to be workable mathematically (Surendra 2010). Walsh et al. (2003) however provides a sharp dismissal of this criticism by arguing that the only social responsibility of the firm is to maximize shareholder value whilst conforming to the rules of society, as this form of maximization would in turn lead to greater social welfare and prosperity. In summary, agency theory is not normative theory. Agency theory's predictive strength lies in description of the situations where parties act rationally, focusing on their personal interest, with risk aversion or unbiased towards risk.

\subsubsection{Theory of Resource Based View of the firm (RBV).}

Rothaermel (2012) defined the resource based view as a theory that emphasizes on the firm's resources as the fundamental determinants of competitive advantage and performance. Firms compete on the basis of their resources and capabilities. This theory was initiated in the mid- 1980s by Wernefelt, Rumelt and Barneyand has since become a dominant contemporary approach to analysis of sustainable competitive advantage. The RBV adopts two assumptions. First, it assumes that firms within an industrymay be heterogenous with regard to the bundle of resources they control and secondly it assumes that the resource heterogeneity may persist over time because the resources used to implement firms' strategies are not perfectly mobile across firms (Peteraf \& Barney, 2003).

The RBV model has been used in the Italian food market to identify characteristics of the SMEs in order to differentiate themselves from other competitors and make a niche in their market. (Barntele et al., 2011). The Italian food firms had been shown to have specificity for raw materials and processes; the capacity to innovate and the capability to establish long term vertical relationships. These characteristics together with marketing and networking, the two strongest internal capabilities of the SMEs, were found to be a driving force for the SMEs to achieve successful performance despite the low level of investment in research and development (Wei \& Wang, 2011). 


\section{International Journal of Science and Research (IJSR) \\ ISSN (Online): 2319-7064}

Index Copernicus Value (2013): 6.14 | Impact Factor (2015): 6.391

Critics of the RBV argued that it lacks operational validity in that it seems to tell managers to develop and obtain valuable, rare, imperfectly imitable and non-substitutable resources but it is silent on how this should be done (Miller, 2003). A related critic is that RBV invokes the illusion of total control and suffers tension between descriptive and prescriptive theorizing (Lado, et al., 2006). However, this critic should not be leveled against the RBV since it was never intended for managerial prescriptions. Furthermore, strategic and entrepreneurial managers are creative and innovative such that they need no prescriptions on how to develop VRIN resources. Another critic is that RBV lacks generalization since it can only apply to large firms with significant market power and the resources that a firm needs to generate SCA are those that are hard to acquire in the first place (Miller, 2003). However, there is an important limit to RBV: in unpredictable environments, we need to go beyond RBV to explain SCA and competitive performance (Barney, 2002). A third critic is that RBV unsuccessfully reaches for a theory of the firm. This is countered by RBV being more of a complement to transaction cost economies (TCE) and hence no need for it to meet the criteria for a theory of the firm.

According to Hitt et al., (2002) integration strategies are related to better company performance. Strategies which are a set of managerial decisions and actions determine the long term performance of a corporation (Hunger \& Wheelen, 1995). According to Sadarsanam (2010) vertically integrated food industries outperform those that are not integrated. He further says that vertical integration influences performance positively while applied under conditions characterized by market failures e.g. high market uncertainty which is commonly observed in the Kenyan rabbit meat market. Sexton did a research to quantify the premium/discount from integration by agribusinesses and food business firms and found a great positive co-relation (2000). In China, the 'Kangda Model' has ensured stable rabbit meat supply for the Chinese local and global market (Yan, 2011); while in Italy farms are often managed by feed supply companies which provide animals, feedstuffs, technical and veterinary support (Coniglionline, 2003). This strategy is a major contributor to these two countries being world leaders in rabbit meat production.

\subsection{Empirical Review}

Researchers from various disciplines have addressed the vertical integration-performance (VI-P) relationship puzzle empirically. Usually the impact of one or more explanatory factors on performance is estimated by using some statistical procedure(s) keeping other factors constant. The findings must be treated critically as data used are retrospective (March and Sutton, 1997). A useful point for assessing past empirical research related to the vertical integration performance (VI-P) relationship is the meta-analysis by Capon et al., (1990). This analysis include 320 empirical studies from different disciplines above, stemming from journals, books, proceedings, dissertations and working papers during the period from 1921 to 1987, where financial performance is the dependent variable. The authors identify 15 studies in which VI (forward or backward) is utilised to examine its effect on financial performance. Several studies use multiple tests, and in 69 cases a positive relationship between VI and financial performance are reported, while 35 reported a negative relationship. Summing up, these studies show a positive relationship (co-variation) between VI and performance.

In South West Nigeria, an analysis of cost for poultry and fish farming carried out by Bamiro et al. (2012) revealed that feed account for $55.8 \%, 68.2 \%$ and $78.9 \%$ of variable cost of production for sole fish farming, integrated poultry and fishery as well as sole poultry farming respectively. In the same order the cost of labour accounted for $26 \%, 6.4 \%$ and $3.7 \%$ of the cost of production. He further reports that horizontal integration was proven to be profitable with a mean gross margin of $€ 1,994,792.88$ which is $22 \%$ and $72 \%$ higher than the gross margin of sole fishery farms and sole poultry farms respectively.

Diagonal integration has been proven to improve company's performance. American Express Europe Limited which got diagonally integrated to offer customer services with the hope that the customers would use them regularly throughout their lives and from this strategic move it generates 34\% of its leisure sales. Ravenscraft and Scherer (2004) also compare the post-merger profitability of different types of mergers. They find that horizontal and related-business mergers tended to be more profitable than conglomerate mergers.

Similarly, Healy, Palepu and Ruback combined financial accounting analysis and stock market event study techniques to examine the post-merger outcomes of 50 large mergers occurring between 1979 and 1984. The authors focus on a comparison of premerger net cash flow returns with postmerger cash flow returns relative to those cash flow returns for the rest of the industry. The authors find that industryadjusted net cash flow rates of return are around 3\% points higher after the merger.

\subsection{Conceptual Framework}

In this study the conceptual framework is provided using dependent variables, independent variables and an intervening variable as well as their relationship as illustrated in the figure 1 below.

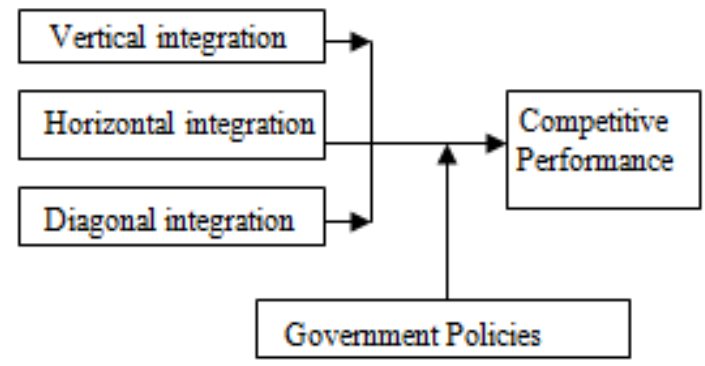

Figure 1: Conceptual Framework

\section{Research Methodology}

This study took a descriptive design of research since this study sought to describe the rabbit meat industry in Kenya and predict the use and outcome of integration strategies by 


\section{International Journal of Science and Research (IJSR) \\ ISSN (Online): 2319-7064 \\ Index Copernicus Value (2013): 6.14 | Impact Factor (2015): 6.391}

the firms involved as well as establish facts about the use of the same. This study adopted a sample survey method. A sample survey was appropriate for this study since it only required a small scale of operation yet it allowed detailed questions to be asked. Also, it allowed characteristics that would otherwise not be tested to be tested

The target population for this study was farm managers and production managers working in all rabbit meat firms in Kenya hence they were the unit of observation while the rabbit meat firms were the unit of analysis. According to MoLD 2015 report, there are 36 farm managers and 33 production managers in the registered rabbit meat production firms in Kenya. They were the target population because of the evident role that managers have in not only day to day running of the firms but also the important role of strategy formulation, implementation and control as well as critical decision making.

The sample size for this study was determined by the use of Narssiuma's formula as shown below to arrive at a sample size of fourty one.

$=\left(\mathrm{N}^{*} \mathrm{C}^{\wedge} 2\right) /\left(\mathrm{C} \wedge 2+(\mathrm{N}-1) \mathrm{e}^{\wedge} 2\right)$

Where $\mathrm{n}=$ sample size

$\mathrm{N}=$ Population Size

$\mathrm{e}=$ tolerable error $(5 \%)$

$\mathrm{C}=$ coefficient of Variation $(0.5)$

$\mathrm{n}=(69 * \llbracket 0.5 \rrbracket \wedge 2) /(\llbracket 0.5 \rrbracket \wedge 2+(69-1) \llbracket 0.05 \rrbracket \wedge(2))$

$=17.25 / 0.42$

$=41.07$ i.e. 41

The rabbit meat production firms in Kenya were categorized into urban, peri-urban and rural firms where each cluster was found to have 5 farms, 11 farms and 20 farms respectively. From these clusters proportionate random sampling was used to select a sample of 41 respondents from 20 farms.

The questionnaires were structured to capture views about vertical integration, horizontal integration and diagonal integration in relation to competitive performance of rabbit meat production firms in Kenya. Likert scale was used in the questionnaire for data collection. Respondents were asked to indicate their level of agreement with each given statement by way of an ordinal scale. The questionnaires were e-mailed to the respondents since this had the ability to reach most of the respondents across a wide geographical area and in a short time.

Content validity of the instruments was assessed by way of expert opinion as put by Saunders (2009), to measure the degree to which the items represented specific areas covered by the study. Cronbach's alpha $(\alpha)$ was used to measure the reliability of the instrument. Variables that returned alpha value of at least equal to 0.7 were considered reliable. The study obtained cronbach's alphas of $0.72,0.75,0.78$ and 0.73 for vertical integration, horizontal integration, diagonal integration and competitive performance. The research instruments were therefore regarded to be reliable .

Pearson's correlation analysis was run to determine the existence and significance of the relationship between vertical integration, horizontal integration as well as diagonal integration; and competitive performance in rabbit meat production in Kenya. The effect of independent variables and the intervening variabe on the dependent variable was presented using the multivariate regression model below:

$\mathrm{Y}=\mathrm{a}+\beta 1 \mathrm{C} 1+\beta 2 \mathrm{C} 2+\beta 3 \mathrm{C} 3+\beta 4 \mathrm{C} 4+\mathrm{e}$

Where:

$\mathrm{Y}=$ Competitive performance

$\mathrm{a}=$ Intercept

$\beta=$ Regression Coefficients to be estimated

$\mathrm{C} 1=$ Vertical integration

$\mathrm{C} 2$ = Horizontal integration

C3 = Diagonal integration

$\mathrm{e}=$ Error term

\section{Results and Discussion}

\subsection{Correlation between integration strategies and competitive performance}

The researcher conducted one tailed Pearson's correlation analysis to determine the correlation between integration strategies and competitive performance of rabbit meat production firms in Kenya. The findings were as presented in table 1.

Table 1: Correlation between integration strategies and competitive performance

\begin{tabular}{|c|c|c|}
\hline & & $\begin{array}{l}\text { Competitive } \\
\text { Performance }\end{array}$ \\
\hline \multirow{3}{*}{$\begin{array}{c}\text { Vertical } \\
\text { Integration }\end{array}$} & Pearson Correlation & \\
\hline & Sig. (1-tailed) & \\
\hline & $\mathrm{N}$ & \\
\hline \multirow{3}{*}{$\begin{array}{l}\text { Horizontal } \\
\text { Integration }\end{array}$} & Pearson Correlation & \\
\hline & Sig. (1-tailed) & \\
\hline & $\mathrm{N}$ & \\
\hline \multirow{3}{*}{$\begin{array}{c}\text { Diagonal } \\
\text { Integration }\end{array}$} & Pearson Correlation & \\
\hline & Sig. (1-tailed) & \\
\hline & $\mathrm{N}$ & \\
\hline \multirow{3}{*}{$\begin{array}{l}\text { Competitive } \\
\text { Performance }\end{array}$} & Pearson Correlation & 1 \\
\hline & Sig. (1-tailed) & \\
\hline & $\mathrm{N}$ & 38 \\
\hline
\end{tabular}

From table 1, using Pearson correlation $r$ and significance value $p$, vertical integration was found to contribute to $62.7 \%$ i.e. $r^{2}=0.632$ at $(r=0.795 ; p<0.01)$ of the positive variation in competitive performance of these firms. On the other hand, diagonal integration was found to contribute $51.9 \%$ i.e. $r^{2}=0.519$ at $(r=0.721 ; p<0.01)$ while horizontal integration was found to insignificantly contribute $1.5 \%$ i.e. $\mathrm{r}^{2}=0.015$ at $(\mathrm{r}=0.126 ; \mathrm{p}<0.01)$.

\subsection{Regression Analysis}

Multiple regression analysis was conducted to establish the linear relationship between integration strategies and competitive performance of rabbit meat production firms in Kenya. The results were as presented in table 2. 


\section{International Journal of Science and Research (IJSR) \\ ISSN (Online): 2319-7064 \\ Index Copernicus Value (2013): 6.14 | Impact Factor (2015): 6.391}

Table 2: Findings of Regression Analysis

\begin{tabular}{|c|c|c|c|c|}
\hline Model & $\mathrm{R}$ & $\begin{array}{c}\mathrm{R} \\
\text { Square }\end{array}$ & $\begin{array}{c}\text { Adjusted R } \\
\text { Square }\end{array}$ & $\begin{array}{c}\text { Std. Error of } \\
\text { the Estimate }\end{array}$ \\
\hline 1 & $.860^{\mathrm{a}}$ & 0.74 & 0.717 & 0.61657 \\
\hline \multicolumn{5}{|c|}{ a. Predictors: (Constant), Diagonal Integration, Horizontal } \\
Integration, Vertical Integration \\
\hline
\end{tabular}

From table 2, R-square of 0.740 indicates that diagonal integration, horizontal integration, vertical integration collectively explain $74.0 \%$ of changes in competitive performance.

\subsection{ANOVA Test}

ANOVA test was used to test the statistical significance of the influence of diagonal integration, horizontal integration, and vertical integration. The findings were as presented in table 3 .

Table 3: ANOVA Results

\begin{tabular}{|l|l|l|l|l|l|l|}
\hline \multicolumn{2}{|l|}{ Model } & Sum of Squares & Df & Mean Square & F & Sig. \\
\hline \multirow{3}{*}{1} & Regression & 36.733 & 3 & 12.244 & 32.208 & $.000^{\mathrm{a}}$ \\
\cline { 2 - 7 } & Residual & 12.926 & 34 & 0.38 & & \\
\cline { 2 - 7 } & Total & $\mathbf{4 9 . 6 5 9}$ & $\mathbf{3 7}$ & \multicolumn{1}{l|}{} & \\
\hline \\
a. Predictors: (Constant), Diagonal Integration , Horizontal Integration, Vertical Integration \\
\hline
\end{tabular}

From ANOVA findings presented in table 3 , significance value of $0.000<0.01$ implies that the overall effect of Diagonal Integration , Horizontal Integration, Vertical Integration on Competitive Performance is statistically significant.

\subsection{Hypothesis Testing}

Hypotheses of the study were tested using regression analysis. The findings were as presented in table 4 .

Table 4: Table of Coefficients

\begin{tabular}{|c|c|c|c|c|c|c|}
\hline \multirow{2}{*}{\multicolumn{2}{|c|}{ Model }} & \multicolumn{2}{|c|}{ Unstandardized Coefficients } & \multirow{2}{*}{$\frac{\text { Standardized Coefficients }}{\text { Beta }}$} & \multirow[b]{2}{*}{$\mathrm{T}$} & \multirow[b]{2}{*}{ Sig. } \\
\hline & & $\mathrm{B}$ & Std. Error & & & \\
\hline \multirow[t]{4}{*}{1} & (Constant) & -1.553 & 1.056 & & -1.47 & 0.151 \\
\hline & Vertical Integration & 0.559 & 0.111 & 0.553 & 5.048 & 0 \\
\hline & Horizontal Integration & 0.282 & 0.221 & 0.121 & 1.274 & 0.211 \\
\hline & Diagonal Integration & 0.694 & 0.186 & 0.438 & 3.739 & 0.001 \\
\hline
\end{tabular}

The first hypothesis was $\mathbf{H o}_{\mathbf{1}}$ : The use of vertical integration strategy has no significant effect on competitive performance of the rabbit meat industry in Kenya. From table 4, $(\mathrm{t}=5.048$, $\mathrm{p}=.000$ ) indicates that there is significant positive effect of use of vertical integration on competitive performance. The first hypothesis was therefore rejected and conclusion made that vertical integration has statistically significant effect on competitive performance. These findings agreed with the findings of Capon et al., (1990) that vertical integration leads to improved financial performance.

The second hypothesis was; $\mathbf{H o}_{2}$ : The use of horizontal integration strategy has no significant effect on competitive performance of the rabbit meat industry in Kenya. The $(t=1.274, p=.211)$ indicates statistical not significant effect of use of horizontal integration on competitive performance. The second hypothesis was therefore accepted and conclusion was made that use of horizontal integration has statistically insignificant effect on competitive performance. The findings disagree with the findings of Bamiro et al. (2012) that horizontal integration is profitable with a mean gross margin higher than the gross margin of sole fishery farms and sole poultry farms respectively. The can also be proven by American Express Europe Limited got diagonally integrated to offer customer services and experienced 34\% improvement in sales. March and Sutton (1997) reported that out that 69 cases had been reported for positive relationship between horizontal integration and financial performance is reported while 35 reported a negative relationship, a report that both supports and conflicts the findings of this study

Lastly, the third hypothesis of the study was; $\mathbf{H O}_{3}$ : The use of diagonal integration strategy has no significant effect on competitive performance of the rabbit meat industry in Kenya. ( $\mathrm{t}=3.739, \mathrm{p}=.001$ ) indicates that there is statistically significant of use of diagonal integration on competitive performance. The last hypothesis was equally rejected and conclusion made that use of diagonal integration has significant effect on competitive performance. The findings concur with the findings of Ravenscraft \& Scherer (2004) that diagonal integration has been proven to improve company's performance. The findings further concur with the findings of Healy et al., (2000) that horizontal and relatedbusiness mergers tended to be more profitable than conglomerate mergers.

From table 4, the following multiple regression model was developed for the study.

$Y=-1.553+0.559 C_{1}+0.282 C_{2}+.694 C_{3}$

Where:

$\mathrm{Y}=$ Competitive performance

$\mathrm{C}_{1}=$ Vertical integration

$\mathrm{C}_{2}=$ Horizontal integration

$\mathrm{C}_{3}=$ Diagonal integration 


\section{International Journal of Science and Research (IJSR) \\ ISSN (Online): 2319-7064}

Index Copernicus Value (2013): 6.14 | Impact Factor (2015): 6.391

\section{Conclusions and Recommendations}

\subsection{Conclusions}

The first conclusion was made that use of vertical integration has statistically significant effect on competitive performance of rabbit meat production firms in Kenya. A firm that adopts vertical integration is better placed to outdo competitors. The study showed that use of horizontal integration has statistically insignificant effect on competitive performance of rabbit meat production firms in Kenya. Horizontal integration therefore may be used as a strategy to achieve competitive advantage. Lastly, there was evidence that there is statistically significant effect use of the use diagonal integration on competitive performance of rabbit meat production firms in Kenya. A firm can adopt diagonal integration as a competitive tool to counteract competitor's strategies.

\subsection{Recommendations and Suggestions for Further Studies}

Firms should have in place internal organizational policy and culture that encourages vertical integration. The firms can adopt vertical integration and a competitive tool to achieve production and operational goal and well as achieve better overall organizational performance. The firms should put into place internal organizational structures that allow cross flow of information so as to allow adoption diagonal integration. This should be a strategic approach led by management and backed with management support.

Further studies should also be done on the role of management in adoption of integration strategies en production environment especially with specific interest on vertical and diagonal integration. Study should be conducted as to whether there the three integration strategies adopted individually would give different results from if they were adopted together. Lastly, a study should be conducted to analyse the effect of culture and religion on competitiveness of the rabbit meat industry in Kenya.

\section{References}

[1] Agresti A, and Finlay, B. (2008) Statistical Options for the Social Sciences, 4th edition. (Upper Saddle River, NJ: Prentice Hall).

[2] Aleri J. W., Abuom T. O., Kitaa J.M., Kipyegon A. N., and Mulei C. M.,, (2012). Clinical presentation, treatment and management of some rabbit conditions in Nairobi. Bull. Animal Health Production Africa, 60: 149-152.

[3] Navarro, A. (2010). Implications of perceived competitive advantages, adaptation of marketing tactics and export commitment on export performance. Journal of World Business, 45(2), 49-58.

[4] Ashoka C. (2013). A Local Solution to Malnutrition Ashoka Changemakers. Nairobi, Kenya.

[5] Bamiro, O.M., O.A. Dayo Phillip \& S. Momoh, (2012). Vertical integration and technical efficiency in poultry (Egg) industry in Ogun and Oyo States, Nigeria.
International Journal of Poultry Science, 5(2), 11641171.

[6] Barney, J. B. (2002). Gaining and Sustaining Competitive Advantage: Prentice Hall.

[7] Berlin, M. 2001. "We control the vertical": three theories of the firm. Federal Reserve Bank of Philadelphia Business Review (Third Quarter): 13 - 22.

[8] Besanko, D, Dranove, D. Shanley, M. \& Schaefer, S. (2007). Economics of Strategy. 4th Edition. 75-186.

[9] Bett H.K., Musyoka M.P., Peters K \& Bokelman W. (2012) Demand for meat in the rural and urban areas of Kenya. A focus on the indigenous chicken, Economics Research International, 11th July, 2012 http://www.hindawi.com/journals/econ/aip/401472/

[10] Borter D.K, \& Mwanza R. N., (2011). Rabbit production in Kenya, Current status \& the way forward.

[11] Caswell, J.A. and Cotterill, R.W. Strategy and Policy in the Food System: Emerging Issues. Washington D.C., Food Marketing Policy Center, Department of Agricultural and Resource Economics, University of Connecticut and Department of Resource Economics, University of Massachusetts, Amherst, 23-38, 1997.

[12] Chen Yifu (2000). The developing tendency of rabbtry in the world. Science farming. 02: 8-9.

[13] Chen Yifu 2007: The tendency of rabbit farming in the world. The extra information. 05 (2), 53-55.

[14] Clavel C. 2004. Small cuniculture family on south coast of Guerrero state, México. In: Proc. 8th World Rabbit Congress, 2004 September, Puebla, Mexico

[15] Dobashi, I., J. Fallon, F. C. Eizmendi, M. Loureiro, K. Matchett, R. Parrish and B. Raquet. (1999). The Value Chain for Poultry. Pacific Basin Economic Council Working Committee on Food Products, March.

[16] EPC (2015): Faostat database Accesible on http://epckenya.org/index.php?option=com_content\&ta sk=view\&id=118\&Itemid=1 $4 . \quad 2012$. available at http://faostat.fao.org

[17] FAOSTAT. (2014). Food and Agriculture Organisation Statistics Database. http://faostat3.fao.org/faostatgateway/go/to/home/E. Accessed May 09, 2014.

[18] Gellynck,X.(2002). Changing Environment and Competitiveness in the Food Industry: Small Firms, Old Traditions Equals Low Profit: Pig Meat Processing in Belgium.

[19] Hunger, J.D. and Wheelen, T.L. (1995) Strategic Management.5th Edition, Addison-Wesley publishing, NY, USA.

[20] Juráskó, R. 2011. Situation of rabbit production in Hungary in 2010. In Proc. 23th Hung. Conf. Rabbit Prod., Kaposvár, Hungary, 3-6.

[21] Lado, A. A., Boyd, N. G., Wright, P., \& Kroll, M. 2006. Paradox and Theorizing Within the

[22] Larsen, J. 2012. Meat Consumption in [the People's Republic of] China Now Double

[23] Love, H. A. \& D. M. Burton. 1997. A rationale for captive supplies.

[24] Maingi, N. \& Nganga, J. (2013). Production characteristics and constraints of rabbit farming in Central, Nairobi and Rift valley provinces. Nairobi, Kenya. 
[25] Miller, D. 2003. An Asymmetry-Based View of Advantage: Towards an Attainable Sustainability. Strategic Management Journal, 24: 961-976.

[26] Moss, C. B. and A. Schmitz. 2000. Vertical integration and trade policy: the case of sugar. Annual Meeting of the American Agricultural Economics Association. Tampa, 31 July - 2 August.

[27] Murray, J. A. (1984), A concept of entrepreneurial strategy. Strat. Mgmt. J., 5: 1-13. MWESNZ (2003) 'Annual Review of the Sheep and Beef Industry 200203' New Zealand Meat and Wool Board's Economic Service, Wellington

[28] Poławska, E., R.G. Cooper, A. Jóźwik, and J. Pomianowski. 2013. Meat from alternative speciesnutritive and dietetic value, and its benefit for human health-a review. J. Food 11:37-42.

[29] Reardon, T. and C. B. Barrett (2000). Agroindustrialization, globalization, and international development. An overview of issues, patterns and determinants. Agricultural Economics, 23: 195-205.

[30] Rivera (2004). The rabbit production in the volcanoes rural area of Ecatzingo village, México, State. In: Proc. 8th World Rabbit Congress, 2004 September, Puebla, Mexico

[31] Rothaermel, F. T. (2012). Strat.Mgmt.: Concepts and Cases. McGraw-Hill/Irwin, p. 5

[32] Serra, V. (2004). A Comparative Study of the Sources of Competitive Advantage in the New

[33] Sexton, R.J. "'Industrialization and Consolidation in the U.S. Food Sector: Implications for Competition and Welfare.' American Journal of Agricultural Economics 82(2000):1087-104.

[34] Sheng Jinglin: The status, outlook and economic analysis of China rabbit farming. Pasturage and veterinary in Jilin.2008.03 (29): 43 45.

[35] Sudarsanam, Sudi. (2010). Creating Value from Mergers and Acquisitions: The Challenges.2nd Edition. p. 124-216.

[36] Powell, T. C. (2001). "Competitive Advantage: Logical and Philosophical Considerations", Strategic Management Journal, 22( 9), 876-877.

[37] World Bank (2012) Doing Business report 2012, Doing business in a more transparent world,

[38] World Bank /IFC, Washington.

[39] Yan Y.K. (2011). The development and direction of China's rabbit industry affected by the raising pattern. Chinese J. of Rabbit Farming, 1 (2011), 1-17.

[40] Zhang M.F. 2010. Problems and Countermeasures of Nowadays Chinese Rabbit Industry.

[41] Zhu M.X., Pan Y.L., Zong J.X. 2009. Review of 30 Years Development of Chinese Rabbit Industry and A Look into The Future. Chinese Journal of Rabbit Farming, 1, 4-6. 